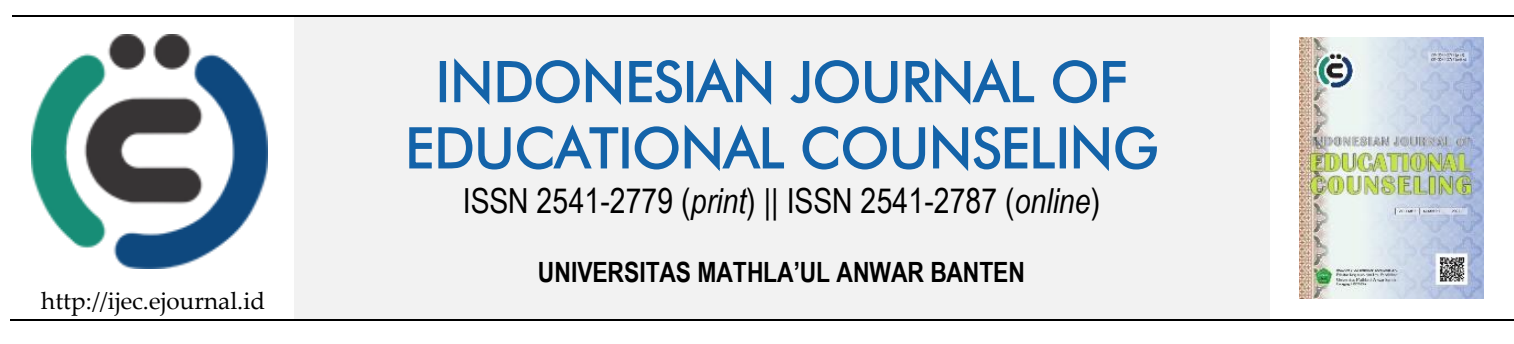

Research Based Article

\title{
Konseling Religi dalam Upaya Menemukan Kebermaknaan Hidup Remaja Korban Broken Home
}

\author{
Rois Nafi'ul Umam ${ }^{1}$, Maemonah² \\ 1,2 UIN Sunan Kalijaga Yogyakarta, Indonesia
}

\begin{tabular}{ll}
\hline Article History & ABSTRACT \\
\hline Received: 28.05.2021 & RELIGIOUS COUNSELING IN AN EFFFORT TO FIND A MEANINGFULL \\
Received in revised form: & LIFE FOR TEENAGER VICTIMS OF BROKEN HOME. The purpose of this \\
01.07 .2021 & research is to explain the phenomenon of teenage victims of broken home in \\
Accepted: 08.07.2021 & their efforts to find meaning in life through religious counseling services. The \\
Available online: 30.07 .2021 & type of this research is phenomenological qualitative. Data collection \\
& techniques were carried out by observation and interviews. The data analysis \\
& technique used intra-case and inter-case analysis. The results showed that the \\
& reasons for these adolescents to attend religious counseling in order to find \\
& meaning in their lives included; forgetting the disappointments they face, \\
& finding wisdom from the problems that occur, finding meaning in life, and \\
& preparing for a new life. Religious counseling is carried out through several \\
& activities such as reading the Koran, listening to lectures, reading Islamic and \\
& motivational books.
\end{tabular}

KEYWORDS: Broken Home, Counseling, Meaningfull Life, Religion, Teenager.

DOI: $10.30653 / 001.202152 .166$

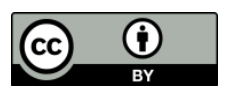

This is an open access article distributed under the terms of the Creative Common Attribution 4.0 International License, which permits unrestricted use, distribution, and reproduction in any medium, provided the original work is properly cited. (c) 2021 Rois Nafi'ul Umam, Maemonah.

\section{PENDAHULUAN}

Masa remaja merupakan bagian dari transisi perjalanan hidup manusia dari masa kanak-kanak menuju masa dewasa (Diananda, 2019). Dalam masa transisi tersebut, terjadi perubahan secara mendasar pada sisi jasmani maupun rohani remaja. Menurut Rice, remaja dapat diartikan dengan masa peralihan individu yang tumbuh dari masa kanakkana menuju masa dewasa yang penuh dengan kematangan, baik secara fisik maupun psikis (Saputro, 2018). Secara fisik, masa remaja dapat ditandai dengan beberapa ciri seperti mulai matangnya organ reproduksi, mengalami menstruasi/mimpi basah, perubahan suara menjadi lebih berat dan munculnya jerawat pada area wajah. Adapun secara psikis, remaja dapat ditandai dengan ciri yang diantaranya memiliki sikap agresif, senang mencoba hal-hal baru, mengalami emosi yang tidak stabil, mulai mencari identitas diri serta memiliki perasaan yang sensitif (Jannah, 2017). Secara psikologis, masa remaja

${ }^{1}$ Corresponding author's address: Program Studi Interdisciplinary Islamic Studies, Konsentrasi Bimbingan Konseling Islam Pascasarjana, UIN Sunan Kalijaga Yogyakarta, Indonesia. E-mail: 2020001107@ student.uinsuka.ac.id 
dapat dikatakan sebagai masa yang labil, yaitu mereka belum sepenuhnya dapat mengendalikan dirinya sendiri secara emosi dan hanya mengikuti naluri dan keingintahuannya tanpa memikirkan dampak yang akan terjadi setelah melakukan hal tersebut. Oleh karenanya dalam masa perkembangannya, remaja perlu untuk dibimbing dan diarahkan oleh orang tuanya agar terhindar dari sikap dan perilaku yang buruk tanpa membatasi dirinya untuk bisa maju dan berkembang (Verawati, 2017).

Salah satu faktor yang berperan penting dalam perkembangan remaja adalah orang tua. Sosok orang tua yang telah melahirkan dan membesarkannya dengan sepenuh hati menjadi pihak yang dapat menentukan perilaku atau arah masa depan yang hendak dicapai oleh remaja tersebut. Keluarga yang bahagia dan harmonis merupakan keluarga yang diidamkan oleh remaja, karena ia dapat merasakan kasih sayang dan perhatian yang selayaknya ia dapatkan dari orang tuanya (Muniriyanto \& Suharnan, 2014). Selain itu dalam keluarga yang bahagia dan harmonis, remaja tersebut diperlakukan dengan selayaknya seorang anak yang mendapatkan bimbingan dan pengasuhan yang baik dari orang tua. Untuk mencapai kebahagiaan dan keharmonisan dalam keluarga, setiap anggota keluarga memiliki peran penting untuk mewujudkan hal tersebut, baik itu ayah, ibu maupun anak-anaknya (Arintina \& Fauziah, 2015). Peran tersebut dijalankan sebagaimana kedudukan mereka dalam rumah tangga, ayah yang berusaha untuk mencari penghidupan yang layak, seorang ibu yang mengurus rumah tangga dan membimbing anak-anaknya, serta anak-anak yang menjalankan tugas dan tanggung jawab yang diberikan dengan baik dan membahagiakan kedua orang tuanya. Melalui keluarga yang bahagia dan harmonis, setiap anggota keluarga di dalamnya akan merasakan damai dan penuh cinta kasih antar sesama anggota keluarga serta dapat mencapai tujuan hidup yang telah ditetapkan oleh masing-masing anggota keluarga (Isminayah \& Supandi, 2016).

Akan tetapi tidak semua keluarga berada pada kondisi yang diliputi dengan kebahagiaan dan keharmonisan. Dalam keluarga tersebut terjadi konflik internal yang menyebabkan renggangnya hubungan antar anggota keluarga. Konflik tersebut dapat diakibatkan oleh permasalahan dalam keluarga yang tidak terselesaikan dengan baik (Isminayah \& Supandi, 2016). Dari konflik internal dalam keluarga tersebut, dapat menghantarkan keluarga tersebut pada perceraian akibat masalah-masalah yang ada tersebut tidak menemui titik temu solusinya. Akibat dari perceraian tersebut, remaja akan kehilangan salah satu sosok dari orang tuanya karena mereka akan tinggal dengan salah satu diantara keduanya (Dewanti \& Ediati, 2016). Secara psikis, remaja tersebut merasa kehilangan orang yang penting dalam hidupnya dan merasakan dampak negatif dari perceraian tersebut. Akibat dari broken home yang terjadi, remaja tersebut akan mengalami gangguan psikologis, seperti merasa insecure, perasaan takut menjadi penyebab perceraian yang dilakukan oleh orang tuanya, merasa dirinya tidak berharga dan depresi yang dapat berujung pada bunuh diri (Ramadhani \& Krisnani, 2019). Remaja yang menjadi korban broken home tersebut dapat kehilangan motivasi untuk hidup serta mencari pelarian lain untuk mengekspresikan perasaannya dengan melakukan perilaku yang merugikan dirinya sendiri atau orang lain.

Fenomena remaja yang menjadi korban dari broken home dan berdampak secara psikologis terhadap pribadi mereka, menjadi sebuah fenomena yang amat perlu untuk dikaji secara mendalam berkaitan dengan kebermaknaan hidup dari remaja tersebut (Wulandri \& Fauziah, 2019). Hal ini dikarenakan para remaja yang menjadi korban broken home tersebut merasa hidupnya hampa, kosong dan tidak bermakna karena kehilangan salah satu sosok orang tua yang selama ini telah mendampinginya dan membimbingnya 
dari kecil. Kehampaan dan ketidak berhargaan dalam diri dapat ditunjukkan dalam bentuk hilangnya semangat untuk menjalani hidup, munculnya perasaan yang absurd, merasa tidak berdaya dan putus asa (Aziz, 2015). Dalam diri remaja tersebut, ia berusaha untuk tetap kuat untuk menghadapi kondisi yang tidak ia harapkan tersebut dan berusaha mencari nilai positif dari kejadian tersebut. Selain itu remaja tersebut akan mencari makna dari setiap perjalanan hidupnya. Akan tetapi tidak semua remaja yang menjadi korban broken home memiliki kemampuan dan menjalani usaha tersebut sehingga ia larut dalam permasalahan yang dapat berdampak secara psikologis terhadap pribadinya tersebut (Hafiza \& Mawarpury, 2018).

Kebermaknaan hidup merupakan sebuah nilai yang mendorong terbentuknya motivasi yang kuat untuk dapat menjalani hidupnya dengan baik, melakukan kegiatan yang berguna serta memberi manfaat kepada diri sendiri dan orang lain. Kebermaknaan hidup dapat dicapai apabila mencapai beberapa indikator meliputi menemukan arti dalam kehidupan yang cocok dengan dirinya, mampu memberi dan menerima cinta serta memiliki tekad yang kuat untuk menjalani hidup (Siddik, Oclaudya, Ramiza, \& Nashori, 2018). Upaya untuk menemukan keberhargan diri dapat dimaknai dengan mengubah kondisi hidup yang tidak bermakna dan mengarahkannya pada hidup yang bermakna. Untuk mencapai kebermaknaan hidup, remaja harus melewati beberapa tahap penting yang diantaranya tahap derita, tahap penerimaan diri, tahap pemaknaan hidup, tahap realisasi makna dan tahap kehidupan bermakna. Kebermaknaan hidup individu dapat dipengaruhi oleh dua faktor yaitu secara internal maupun eksternal. Faktor internal meliputi pola berpikir, sikap, konsep diri, kepercayaan dan kepribadian. Adapun faktor eksternal diantaranya adalah pekerjaan, pengalaman, hubungan dalam keluarga dan kebudayaan lokal (Mazaya \& Supradewi, 2020). Dalam konteks remaja yang menjadi korban broken home, hubungan antar anggota keluarga yang tidak harmonis dan berujung pada perceraian membuat remaja korban broken home tidak memiliki kebermaknaan dalam hidup, merasa hampa dan tidak semangat dalam menjalani hidup. Para remaja tersebut menghendaki kehidupan yang berjalan dengan semestinya, akan tetapi hal tersebut tidak ia dapatkan ketika remaja tersebut menghadapi kondisi yang tidak ideal yaitu broken home.

Dalam penelitian lainnya yang dilakukan oleh Deviana Citra Dewi Widyawati menunjukkan bahwa tidak semua remaja larut dalam kesedihan dan menjadikan dirinya hidup dengan ketidakbermaknaan ketika mengalami broken home. Mayoritas remaja yang menjadi subjek penelitian tersebut memiliki makna hidup yang baik dan tetap semangat dalam menjalani hidupnya (Widyawati, 2009). Hal ini berbanding terbalik dengan penelitian yang dilakukan oleh Yuniar Asih yang menyatakan bahwa kebermaknaan hidup bagi remaja broken home hanya dirasakan oleh sedikit remaja dan lebih banyak remaja yang merasakan ketidak bermaknaan dalam hidupnya (Mustikarani, 2013). Adapun perbedaan dengan beberapa penelitian diatas, penelitian yang dilakukan oleh peneliti berfokus pada upaya menemukan keberhargaan diri bagi remaja korban broken home melalui konseling religi yang dilaksanakan di rumah konseling mutiara hati. Dalam hal ini remaja yang menjadi subjek penelitian akan berusaha untuk menemukan keberhargaa melalui tahapan-tahapan dalam konseling religi yang dilaksanakan di rumah konseling mutiara hati.

Konseling religi merupakan proses pemberian bantuan yang dilakukan oleh konselor kepada konseli yang sedang mengalami permasalahan agar konseli tersebut dapat menyelesaikan masalah yang sedang dihadapinya. Dalam konseling religi, nilainilai dasar dalam agama dan kepercayaan akan diserap dan diadaptasi dalam layanan 
konseling, sehingga dapat membentuk nilai yang dapat dipahami oleh konseli dan dapat mengembangkan dirinya berlandaskan nilai-nilai moral keagamaan (Maulana \& Hernisawati, 2017). Melalui konseling religi, diharapkan konseli dapat mengembangkan potensi diri, kemampuan berpikir, keimanan dan ketakwaan untuk mencapai pribadi yang baik berlandaskan pada nilai-nilai keagamaan.

Dari latar belakang di atas, penelitian ini akan berfokus pada alasan dari remaja yang menjadi korban broken home tersebut untuk mengikuti konseling religi dalam rangka menemukan kebermaknaan hidup dan proses yang dilalui dalam konseling religi untuk mencapai kebermaknaan hidup. Adapun rumusan masalah dalam penelitian ini adalah apa alasan dari remaja tersebut untuk mengikuti konseling religi dalam mencapai kebermaknaan hidup? Bagaimana proses dalam konseling religi untuk mencapai kebermaknaan hidup?

\section{METODE}

Jenis penelitian yang digunakan adalah penelitian lapangan (field research) yang dilaksanakan di rumah konseling keluarga mutiara hati. Adapun metode yang digunakan dalam penelitian ini adalah kualitatif fenomenologis. Hal ini dikarenakan peneliti berfokus untuk mengamati dan menggambarkan dari kebermaknaan hidup yang dikehendaki oleh remaja korban broken home melalui pendekatan kualitatif fenomenologi ini. Teknik pengumpulan data dilakukan dengan observasi dan wawancara secara singkat terhadap subjek penelitian ini yaitu remaja korban broken home. Melalui teknik pengumpulan data tersebut, peneliti dapat mengetahui riwayat pribadi dan permasalahan yang dihadapinya, serta proses yang dihadapi oleh subjek penelitian untuk menemukan kebermaknaan hidup. Jumlah subjek dalam penelitian ini sebanyak 2 orang, yaitu konselor berjumlah 1 orang dan konseli sebanyak 1 orang. Teknik analisis data dilakukan dengan teknik analisis intra kasus dan antar kasus untuk memperoleh gambaran umum mengenai kehidupan pribadi subjek penelitian, permasalahan yang dialami oleh subjek penelitian, dan upaya dalam menemukan kebermaknaan hidup melalui konseling religi yang diikutinya.

\section{HASIL DAN PEMBAHASAN}

Broken home merupakan retaknya rumah tangga/keluarga yang telah terbangun yang terjadi akibat anggota keluarga yang tidak dapat menjalankan peran sosial atau menjalankan kewajibannya. Broken home terjadi dalam bentuk tanpa hadirnya salah satu dari orang tua, baik ayah ataupun ibu akibat dari perceraian atau meninggalkan rumah. Broken home dalam keluarga dapat terjadi akibat pertengkaran antar anggota keluarga dan tidak adanya sikap dan bentuk kasih sayang dalam lingkungan keluarga (Novianto, Zakso, \& Salim, 2017). Keluarga yang mengalami broken home dapat diidentifikasi dengan beberapa ciri yang diantaranya adalah orang tua bercerai, hubungan antara ayah dan ibu atau antara orangtua dengan anak yang kurang baik, serta suasana dalam rumah yang tegang karena penuh dengan masalah serta tidak ada upaya untuk bersama-sama menyelesaikan masalah tersebut (Muttaqin \& Sulistyo, 2019). Kondisi keluarga yang mengalami broken home yang diliputi dengan ketegangan dan konflik antar anggota keluarga berdampak secara psikologis terhadap anggota keluarga lainnnya. Salah satu yang merasakan dampak langsung secara psikologis dari kasus broken home adalah anak/remaja. Seorang remaja yang seharusnya mendapatkan arahan dan bimbingan dari 
orang tuanya, justru dihadapkan dengan kasus broken home yang terjadi pada keluarganya. Dampak negatif yang dirasakan oleh remaja dari kasus broken home adalah menjadi tidak percaya diri, memiliki emosi yang tidak stabil, rentan menjadikannya berperilaku agresif, kehilangan motivasi dan tujuan hidup serta tidak menemukan kebermaknaan dalam hidupnya. Jika hal ini tidak ditangani dengan cepat dan tepat, maka sikap dan perilaku ini akan terbawa hingga dewasa dan membuatnya menjadi individu yang bersikap temperamental serta mencari pelampiasan dengan cara yang buruk (Fitria \& Ifdil, 2020).

Salah seorang remaja yang menjadi subjek dalam penelitian ini merasakan hal-hal yang dimaksud diatas seperti tidak menemukan kebermaknaan dalam hidupnya. Keluarga dari remaja tersebut baru saja mengalami broken home yang berujung pada perceraian. Akibat dari perceraian tersebut, remaja itu hanya tinggal dengan salah seorang dari orang tuanya dan kehilangan salah satu sosok orang tua yang selama ini telah membimbing dan mengarahkannya dalam perjalanan hidupnya. Remaja tersebut merasa tidak percaya diri dengan kondisinya saat ini, merasa tidak bersemangat untuk menjalani hidup, kehilangan kebermaknaan dalam hidup serta berpikir untuk mengakhiri hidup. Dari wawancara yang dilakukan oleh peneliti dengan subjek penelitian, diketahui bahwa remaja tersebut mengikuti konseling religi atas rekomendasi dari pihak keluarga agar remaja tersebut kembali pulih secara psikologis dan tidak lagi trauma dengan kasus broken home yang terjadi. Menurut subjek penelitian, kesediaannya untuk mengikuti konseling religi di rumah konseling mutiara hati didasarkan pada keinginan untuk mengalihkan kesedihan yang dirasakannya menjadi pribadi yang lebih baik. Berikut akan dijelaskan alasan kesediaan dari remaja tersebut untuk mengikuti konseling religi yang dilaksanakan di rumah konseling mutiara hati.

\section{Melupakan Kekecewaan yang Dihadapinya}

Rasa kecewa yang dirasakan oleh subjek penelitian berkenaan dengan kasus broken home yang terjadi pada keluarganya membuatnya larut dalam suasana yang kesedihan dan suasana yang tidak menentu. Subjek tersebut belum dapat menerima keputusan yang diambil oleh orang tuanya yang memutuskan untuk bercerai. Subjek merasakan kekecewaan yang menurutnya belum pernah ia rasakan sebelumnya. Akan tetapi kemudian subjek menyadari bahwa ia tidak bisa untuk terus berada dalam kondisi yang penuh dengan kekecewaan. Subjek tersebut memiliki keinginan untuk melakukan konseling agar ia dapat melupakan kekecewaan yang dirasakannya selama ini akibat dari kasus broken home tersebut. Subjek tersebut berkata:

"Setelah mengetahui keluarga saya mengalami broken home dan kedua orang tua memutuskan untuk bercerai, disitu saya langsung kecewa sejadi-jadinya dengan orang tua saya yang mengambil keputusan seperti itu. Ketika itu saya masih berharap orang tua saya tidak berpisah, akan tetapi Tuhan berkehendak lain dan akhirnya keluarga saya hancur saat itu juga. Saya khawatir tidak dapat beradaptasi ketika tidak lagi tinggal bersama salah satu dari orang tua saya dan saya takut jika nanti mengalami bullying karena broken home yang terjadi pada keluarga saya. Setelah beberapa lama, saya menyadari bahwa hidup terus berjalan dan saya tidak bisa secara terus menerus berada dalam kondisi yang seperti ini. Saya ingin menjadi lebih baik dan saya perlu dukungan untuk menjadi lebih baik dan dukungan itu yang saya dapatkan di rumah konseling mutiara hati ini" (IN, wawancara 13 April 2021).

Menurut subjek tersebut dengan melakukan konseling berbasis religi di rumah konseling mutiara hati, ia merasa lebih tenang dan berusaha untuk melupakan 
kekecewaan yang pernah dirasakannya, sebagaimana yang diungkapkan oleh subjek berikut:

"saya merasa bahwa konseling religi yang dilaksanakan di rumah konseling mutiara hati ini saya belajar tentang ikhlas, berpikir lebih dewasa dalam menghadapi masalah serta dapat membantu mengatasi masalah saya" (IN, wawancara 13 April 2021).

\section{Menemukan Hikmah dari Masalah yang Terjadi}

Kasus broken home yang terjadi pada keluarga subjek, menimbulkan dampak secara psikologis terhadap subjek. Subjek merasa bahwa hidupnya telah berubah dan tak akan lagi sama seperti sebelum broken home terjadi. Menurut subjek, ia selalu berpikir negatif atas kasus broken home yang terjadi, baik itu penyebab dari perceraian yang dilakukan orang tuanya maupun masa depannya setelah kasus broken home ini terjadi. Setelah beberapa waktu, ia menyadari bahwa di balik sebuah kejadian yang tidak menyenangkan, terdapat hikmah atau nilai positif yang dapat diambil. Untuk dapat menemukan hikmah dari kejadian tersebut, ia memutuskan untuk mengikuti konseling religi tersebut. Berikut adalah ungkapan dari subjek penelitian:

"Ketika orang tua saya memilih untuk bercerai, saya merasa bahwa kehidupan saya akan berbeda antara sebelum dan sesudah perceraian ini. Di masa lalu saya merasakan kasih sayang yang sepenuh hati dari kedua orang tua saya, dan kedepannya mungkin saya tidak merasakan itu lagi, kasih sayang yang saya dapat tidak akan seperti dulu atau saya mungkin tidak akan merasakan kasih sayang itu lagi. Terkadang saya juga berpikir negatif tentang penyebab perceraian orang tua saya, dan saya merasa menjadi penyebab dari perceraian diantara keduanya. Saya kadang menceritakan ini kepada sahabat yang saya percaya dan dia menyarankan agar saya berusaha untuk berpikir positif dan mengambil hikmah positif dari masalah broken home yang terjadi. Setelah ada kesempatan untuk mengikuti konseling, disitu saya sekaligus mengusahakan untuk mencari hikmah positif dari kejadian tersebut dengan konselor yang sangat-sangat baik menurut saya. Setelah mengikuti konseling religi yang dilaksanakan di rumah konseling mutiara hati ini, dengan bantuan dari konselor, saya udah berdamai dengan masa lalu dan siap untuk menjalani hidup yang baru di masa yang akan datang. Selain itu saya sudah menemukan hikmah positif dari kejadian broken home di keluarga saya dan sudah menerima kejadian dan keputusan itu dengan ikhlas" (IN, wawancara 13 April 2021).

\section{Menemukan Kebermaknaan Hidup}

Masalah broken home yang terjadi pada keluarga subjek membuatnya kehilangan arah, motivasi dan tujuan hidup serta tidak mengetahui arti dan makna dari kehidupan yang dijalaninya saat ini. Hal ini dikarenakan ketidaksiapan dari subjek dalam menghadapi masalah yang terjadi dan suasana baru yang dirasakan setelah adanya kasus broken home tersebut. Subjek kemudian menyadari bahwa ia harus menjadi lebih baik dan menemukan makna atau arti dalam perjalanan hidupnya. Hal ini dilakukannya agar subjek tidak terjebak dalam suasana kesedihan yang selama ini telah ia jalani. Menurutnya melalui kebermaknaan hidup, ia dapat menghayati setiap perjalanan hidup yang dijalani, mengambil makna dari setiap kejadian, selalu berpikir positif jika ada hal yang tidak dikehendaki untuk mencapai kebahagiaan dalam hidupnya. Hal inilah yang mendorong subjek untuk berusaha menemukan kebermaknaan hidupnya melalui konseling religi yang dilaksanakan di rumah konseling mutiara hati. Ia berharap setelah mengikuti 
konseling religi tersebut, ia dapat menjadi pribadi yang lebih baik, menemukan kebermaknaan dalam hidupnya, serta memiliki motivasi dan tujuan hidup di masa yang akan datang. Berikut adalah pemaparan selengkapnya dari subjek penelitian:

“Hidup yang bermakna menurut saya yaitu ketika saya dapat menghayati, meresapi dan mendalami setiap bagian dari perjalanan hidup yang dijalani. Selain itu hidup kita menjadi lebih bermakna ketika kita dapat mengambil sisi positif dari sebuah kejadian selalu meyakini bahwa hal tersebut telah diatur oleh yang maha kuasa dan kita meyakini dibalik hal itu ada nilai-nilai positif yang bisa diambil. Untuk menemukan kebermaknaan hidup, saya memutuskan untuk mengikuti konseling religi ini agar hidup dengan bantuan konselor di rumah konseling mutiara hati ini. Setelah mengikuti konseling religi ini, saya jadi mengerti bahwa kebermaknaan hidup saya dijalankan dengan memberi manfaat untuk diri saya sendiri dan orang lain, dan ketika saya tidak bisa melakukan itu, rasanya seperti menyia-nyiakan kesempatan yang mungkin tidak setiap waktu akan datang. Selain itu saya menyadari bahwa kebermaknaan dalam hidup saya ditunjukkan dengan membuat rencana dan tujuan yang baik dan sesuai dengan kemampuan saya serta dapat mengisi waktu yang luang dengan sesuatu yang bermanfaat seperti mempelajari ilmu agama" (IN, wawancara 13 April 2021).

\section{Menyiapkan Diri untuk Kehidupan yang Baru}

Setelah subjek telah menerima masalah broken home yang terjadi pada keluarganya, ia berharap dapat menjalani hidup baru dengan baik, tidak lagi terbawa dengan masalah di masa lalu serta yakin dan optimis bahwa kehidupan berikutnya akan menjadi lebih baik. Dengan dasar keyakinan tersebut, ia mencoba untuk mengikuti konseling religi dengan konselor di rumah konseling mutiara hati.Harapannya adalah, konselor tersebut bisa membantunya untuk menyiapkan diri untuk menjalani kehidupan yang baru dan suasana yang baru. Berikut adalah pemaparan dari subjek penelitian:

"Saya berusaha untuk menerima kejadian tersebut dan berusaha untuk beradaptasi dengan kehidupan yang baru setelah terjadi perceraian kedua orang tua saya itu. Saya berusaha untuk mencoba menjalani hidup yang baru dan tidak lagi mengingatingat masalah yang pernah terjadi di masa lalu. Akan tetapi rasanya berat untuk menjalani hal itu, dan saya butuh bantuan dan orang yang dapat mengerti perasaan saya dan dapat membantu saya untuk merencanakan dan memulai kehidupan yang baru ini. Oleh karenanya saya kemudian mengikuti konseling disini agar saya kedepannya dapat menjalani hidup dengan baik dan tanpa ada beban pikiran lagi perihal broken home yang pernah terjadi" (IN, wawancara 13 April 2021).

Kebermaknaan hidup sebagai sebuah nilai fundamental bagi setiap manusia dalam menjalani hidupnya agar manusia dapat menemukan arti dan makna dari setiap perjalanan hidupnya serta menikmati hidup yang dijalaninya tersebut. Kebermaknaan dalam hidup dimaknai dengan upaya untuk menjadikan hidup yang lebih berarti dan bermanfaat, baik untuk diri sendiri maupun lingkungan sekitarnya. Melalui kebermaknaan hidup tersebut, individu dapat mencapai tujuan dan motivasi hidup, memberi kebermanfaatan bagi orang lain dan memperoleh kebahagiaan bagi individu tersebut (Andriyan \& Rumtianing, 2020). Dalam konteks keagamaan, khususnya dalam Islam, kebermaknaan hidup dapat dicapai ketika manusia dapat mengetahui arti dari kehidupannya, menerima atas segala yang telah ditetapkan dan terjadi padanya serta selalu yakin bahwa dibalik sebuah ujian, akan ada kebahagiaan yang akan diberikan 
olehnya sebagai balasan atas kesabaran dan usahanya dalam menjalani ujian yang diberikan oleh Tuhannya tersebut (Ningsih, Reza, \& Uyun, 2017).

Untuk dapat mencapai kebermaknaan dalam hidupnya, manusia perlu menyadari bahwa hidup yang dijalaninya perlu dimaknai secara mendalam dan senantiasa berusaha untuk selalu berbuat baik dan memberi manfaat. Terkadang manusia menyadari pentingnya kebermaknaan hidup saat ia berada dalam kondisi yang sulit dan diliputi dengan permasalahan yang rumit. Saat mengalami hal tersebut, manusia akan berusaha untuk mencari solusi atas permasalahannya dan juga menemukan kebermaknaan dalam hidupnya ketika ia merasa tak lagi memiliki motivasi dan tujuan dalam hidupnya (Hidayat, 2019). Ketika manusia berada dalam kondisi yang sulit tersebut, ia memerlukan dukungan dan orang lain di sekitarnya yang mampu mengarahkannya untuk menemukan kebermaknaan dalam hidupnya. Salah satu upaya yang dapat dilakukan untuk menemukan kebermaknaan dalam hidup adalah dengan layanan konseling. Konseling merupakan pemberian bantuan yang diberikan oleh konselor kepada konseli dalam rangka untuk membantu penyelesaian masalah yang dihadapi oleh konseli. Dalam layanan konseling, konseli dapat menyampaikan permasalahan yang dihadapinya dan konselor membantu mengarahkan konseli tersebut untuk mencari alternatif penyelesaian masalahnya (Sukma, 2018).

Dalam konteks remaja yang menjadi korban broken home diatas, layanan konseling dilakukan untuk membantu dirinya dalam menyelesaikan masalah dan menemukan kebermaknaan dalam hidupnya untuk mencapai kebermanfaatan dan kebahagiaan dalam hidupnya. Adapun jenis konseling yang diikuti oleh subjek penelitian ini yaitu konseling religi yaitu layanan konseling yang menginternalisasi nilai-nilai religiusitas dalam keagamaan. Adapun penggunaan konseling religi ini didasarkan pada kebermaknaan hidup yang dikehendaki tidak terlepas dari nilai-nilai spiritual dan nilai tersebut menjadi pendukung dalam membantu subjek untuk mencapai kebermaknaan dalam hidupnya. Layanan konseling religi ini dijalankan dalam empat tahap dan berikut adalah tahapan-tahapan dari konseling religi:

\section{Tahap Awal}

Dalam tahap awal ini, konselor akan menyambut konseli dan memperkenalkan dirinya kepada konseli. Setelah itu konselor memperkenalkan layanan konseling secara umum seperti tujuan dari konseling, asas konseling, aturan-aturan yang harus ditaati dalam proses konseling serta tujuan yang hendak dicapai dari konseling. Selain itu, konselor juga memperkenalkan mengenai konseling religi yang dilandasi oleh nilai-nilai spiritual dalam Alquran. Untuk dapat membangun hubungan yang bersifat kekeluargaan dan tidak memberikan suasana yang tegang bagi konseli, suasana konseling yang dibangun bersifat santai dan memberikan rasa tenang bagi konseli untuk dapat menceritakan permasalahan yang dihadapinya serta dapat mengikuti layanan konseling dengan perasaan yang nyaman. Setelah terbangun hubungan yang baik antara konselor dan konseli, kemudian keduanya menegosiasikan kontrak perihal waktu, tugas dan kerjasama selama proses konseling. Setelah menandatangani kontrak perjanjian, konseli akan diberi kesempatan untuk menceritakan masalah yang dihadapinya kepada konselor. Setelah konseli menyampaikan masalah yang dihadapinya, konselor kemudian memperjelas masalah yang dihadapi oleh konseli dan mendefinisikan masalah yang disampaikan konseli untuk menentukan langkah-langkah yang akan diambil pada tahap berikutnya. 


\section{Tahap Kegiatan}

Tahap ini merupakan tahap inti dari layanan konseling religi ini, karena fokus dari konseling yang dijalankan berada pada tahap ini. Setelah mengetahui dan mendalami permasalahan yang dihadapi oleh konseli, kemudian konselor menyampaikan rencana intervensi yang akan dilakukan dalam konseling. Mengingat bahwa konseling yang dilakukan merupakan konseling religi, maka kegiatan yang dilakukan berlandaskan pada nilai-nilai dan ajaran agama, khususnya Islam. Adapun pada tahap ini kegiatan yang dilakukan meliputi membaca Alquran, mendengar ceramah, membaca buku-buku motivasi dan keislaman serta membuat rencana dan tujuan hidup yang dikehendaki ketika konseli telah selesai melakukan layanan konseling. Semua kegiatan yang dilaksanakan tersebut, didampingi konselor untuk memastikan setiap prosesnya dapat berjalan dengan baik. Pada kegiatan membaca Alquran, konseli dihadapkan dengan ayatayat yang memiliki makna yang mendalam dan motivasi seperti surah yusuf ayat 87, surah At-Taubah ayat 40, surah Ali Imran ayat 139, surah A-Baqarah ayat 216 dan surah Ath-Thalaq ayat 2-3 yang kemudian dapat diambil hikmahnya oleh konseli tersebut. Kegiatan berikutnya adalah dengan mendengar ceramah yang disampaikan oleh ustadz, dalam hal ini ustadz yang menjadi rujukan bagi konseli dalam belajar agama. Konseli mendengarkan ceramah dengan tema yang sesuai dengan permasalahan yang dihadapinya, upaya dalam menemukan kebermaknaan hidup serta motivasi bagi dirinya untuk dapat menjadi pribadi yang lebih baik. Setelah kegiatan membaca Alquran dan mendengarkan ceramah telah dilakukan, kegiatan berikutnya yang dilakukan pada tahap ini yaitu konseli dapat membaca buku-buku mengenai motivasi dan keislaman. Adapun buku-buku yang dibaca sesuai dengan karakteristik konseli dan mengandung isi yang dapat menguatkan sisi positif konseli dan membantunya dalam mencapai kebermaknaan hidup serta dapat memberikan motivasi bagi konseli untuk menjadi lebih baik. Kemudian masuk pada kegiatan terakhir yaitu menuliskan upayanya untuk berdamai dengan masa lalu, cita-cita tujuan dan arah hidupnya di masa yang akan datang, serta kebermaknaan hidup yang telah ia temukan dari kegiatan yang telah dilaksanakan sebelumnya, yaitu membaca alquran, mendengar ceramah dan membaca buku motivasi dan keislaman.

\section{Tahap Akhir}

Setelah melalui rangkaian kegiatan yang dilaksanakan pada tahap sebelumnya dalam proses konseling, konseli merasakan perubahan positif yang ada pada dirinya dan menemukan kebermaknaan hidup yang dikehendakinya. Perubahan-perubahan tersebut meliputi kesediaan untuk menerima masalah yang terjadi dan mengambil sisi positif dari masalah tersebut, menemukan kebermaknaan dalam hidupnya yaitu konseli menyadari bahwa setiap bagian dari perjalanan hidupnya merupakan sesuatu yang bernilai dan memiliki makna yang mendalam dan menghayati setiap detik-detik dalam kehidupannya agar menjadikannya sebagai manusia yang bersyukur, memberi manfaat bagi diri sendiri dan orang lain. Adapun rencana dalam kehidupan yang baru menurut konseli diisi dengan kegiatan-kegiatan yang bermanfaat bagi dirinya, memberi manfaat bagi orang lain serta tidak bertentangan dengan ketentuan Agama. Selain itu, konseli telah mempersiapkan rencana untuk membahagiakan orang tuanya walaupun salah satu dari mereka tidak lagi tinggal bersama dengan konseli tersebut. Sebelum konseling diakhiri, konselor dan konseli menyampaikan evaluasi atas konseling yang telah dilakukan dan mengatur pertemuan apabila konseli kembali mengalami kendala berhubungan dengan kebermaknaan dalam hidupnya. 


\section{SIMPULAN}

Masalah broken home yang terjadi pada keluarga, dapat berdampak pada anggota keluarga yang lain, salah satunya adalah remaja dalam keluarga tersebut. Dampak negatif dari broken home berpengaruh terhadap kondisi psikologis remaja yang sedang berada pada masa perkembangan, dan membuatnya kehilangan arah, tujuan, motivasi hidup serta kebermaknaan yang ada dalam hidupnya. Untuk dapat membantu remaja tersebut dalam menemukan kebermaknaan hidupnya, dapat dilakukan melalui konseling religi yang dilandasi oleh nilai-nilai keagamaan. Konseling religi diisi dengan kegiatan seperti membaca Alquran, mendengar ceramah dan membaca buku-buku motivasi dan keislaman yang dapat membantunya dalam menemukan kebermaknaan hidup dan upayanya untuk berdamai dengan masalah broken home yang dihadapinya. Setelah mengikuti konseling religi, remaja tersebut telah menemukan kebermaknaan dalam hidupnya, menerima dengan lapang dada permasalahan broken home yang terjadi dan mengambil sisi positifnya serta menyiapkan diri untuk menjalani kehidupan yang baru dengan rencana yang telah ditetapkan.

\section{REFERENSI}

Andriyan, \& Rumtianing, I. (2020). Kebermaknaan hidup Lansia (Studi kasus di cabang UPT Pelayanan Sosial Tresna Werdha Magetan Jawa Timur). Rosyada: Islamic Guidance and Counseling, 1(1), 72-89.

Arintina, Y. C., \& Fauziah, N. (2015). Keharmonisan keluarga dan kecenderungan berperilaku agresif pada siswa SMK. Jurnal Empati, 4(1), 208-212.

Aziz, M. (2015). Perilaku sosial anak remaja korban broken home dalam berbagai perspektif (Suatu penelitian di SMPN 18 kota Banda Aceh). Jurnal Al-Ijtimaiyyah, 1(1), 30-50.

Dewanti, W., \& Ediati, A. (2016). Sikap remaja laki-laki dan perempuan terhadap perceraian: Studi komparasi pada remaja siswa SMA Negeri 6 Semarang. Jurnal Empati, 5(3), 594-597.

Diananda, A. (2019). Psikologi remaja dan permasalahannya. Journal ISTIGHNA, 1(1), 116133.

Fitria, L., \& Ifdil. (2020). Kecemasan remaja pada masa pandemi Covid-19. Jurnal EDUCATIO: Jurnal Pendidikan Indonesia, 6(1), 1-4.

Hafiza, S., \& Mawarpury, M. (2018). Pemaknaan kebahagiaan oleh remaja broken home. Psympathic: Jurnal Ilmiah Psikologi, 5(1), 59-66.

Hidayat, V. (2019). Kebermaknaan hidup pada mahasiswa semester akhir. Jurnal Psikologi Integratif, 6(2), 141.

Isminayah, A., \& Supandi. (2016). Relasi tingkat keharmonisan keluarga dengan konsep diri remaja. Al-Balagh : Jurnal Dakwah dan Komunikasi, 1(2), 233-245.

Jannah, M. (2017). Remaja dan tugas-tugas perkembangannya dalam Islam. Psikoislamedia : Jurnal Psikologi, 1(1), 243-256.

Maulana, A., \& Hernisawati. (2017). Konseling religi untuk mengembangkan karakter konseling. Jurnal Islamic Counseling, 1(2), 55-65. 
Mazaya, K. N., \& Supradewi, R. (1970). Konsep diri dan kebermaknaan hidup pada remaja di panti asuhan. Proyeksi, 6(2), 103-112

Muniriyanto, \& Suharnan. (2014). Keharmonisan keluarga, konsep diri dan kenakalan remaja. Persona: Jurnal Psikologi Indonesia, 3(2), 156-164.

Mustikarani, A. Y. (2013). Makna hıdup pada mahasıswa yang mengalamı broken home. Skripsi. Bandung: Universitas Pendidikan Indonesia

Muttaqin, I., \& Sulistyo, B. (2019). Analisis faktor penyebab dan dampak keluarga broken home. Studi Gender dan Anak, 6, 245-256.

Ningsih, D. A., Reza, I. F., \& Uyun, M. (2017). Kebermaknaan hidup lansia pemulung yang beragama Islam di tempat pembuangan akhir (TPA) Sukajaya Kecamatan Sukarame Palembang. Psikis: Jurnal Psikologi Islami, 3(1), 52-59.

Novianto, R., Zakso, A., \& Salim, I. (2017). Analisis dampak broken home terhadap minat belajar siswa SMA Santun Untan Pontianak. Jurnal Pendidikan dan Pembelajaran Khatulistiwa, 8(3), 1-8.

Ramadhani, P. E., \& Krisnani, H. (2019). Analisis dampak perceraian orang tua terhadap anak remaja. Focus: Jurnal Pekerjaan Sosial, 2(1), 109-119.

Saputro, K. Z. (2018). Memahami ciri dan tugas perkembangan masa remaja. Aplikasia: Jurnal Aplikasi Ilmu-Ilmu Agama, 17(1), 25.

Siddik, I. N., Oclaudya, K., Ramiza, K., \& Nashori, F. (2018). Hubungan antara 1khlas dan dukungan sosial dengan kebermaknaan hidup pada orang dengan HIV/AIDS. Psikoislamedia Jurnal Psikologi, 3(1), 98-114.

Sukma, D. (2018). Concept and application group guidance and group counseling base on Prayitno's paradigms. Konselor, 7(2), 49-54.

Verawati, I. (2017). Dukungan sosial orangtua dalam mengikutsertakan anaknya berlatih di Krakatau Taekwondo klub Medan. Jurnal Edutech, 3(2), 22-28.

Widyawati, D. C. D. (2009). Studi kasus tentang kebermaknaan hidup remaja yang orangtuanya bercerai. Yogyakarta: Universitas Sanata Dharma.

Wulandri, D., \& Fauziah, N. (2019). Pengalaman remaja korban broken home (Studi kualitatif fenomenologis). Empati, 8(1), 1-9. 